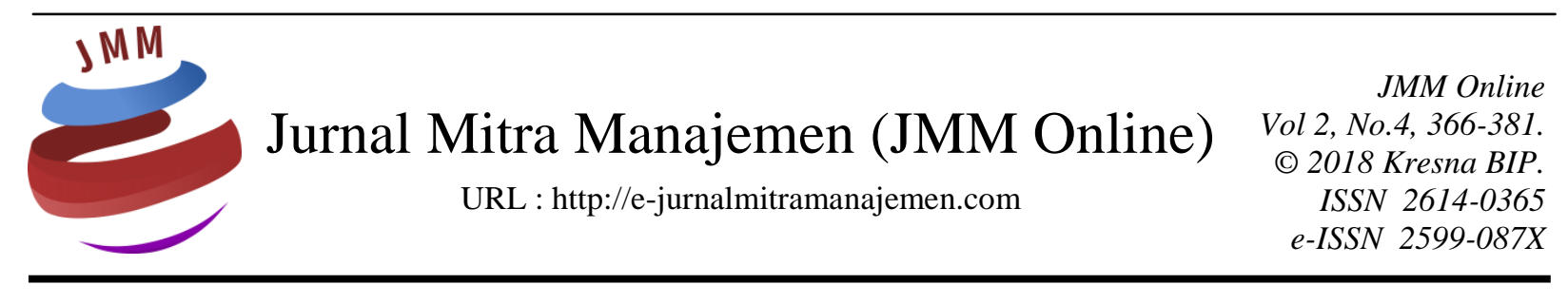

\title{
PENGARUH PERSEPSI DUKUNGAN ORGANISASI, KEPUASAN KERJA DAN KOMITMEN AFEKTIF TERHADAP ORGANIZATIONAL CITIZENSHIP BEHAVIOR
}

\author{
Dewi Cahyani Pangestuti \\ Universitas Pembangunan Nasional "Veteran" Jakarta
}

\section{INFORMASI ARTIKEL}

Dikirim : 13 Juli 2018

Revisi pertama : 21 Juli 2018

Diterima : 26 Juli 2018

Tersedia online : 28 Juli 2018

Kata Kunci : Persepsi Dukungan Organisasi, Kepuasan Kerja, Komitmen Afektif, Organizational Citizenship Behavior $(O C B)$

Email :dewichepe@yahoo.com

\section{ABSTRAK}

Tujuan penelitian ini untuk menganalisis pengaruh dukungan organisasi (POS) $X_{1}$, kepuasan kerja (SAT) $X_{2}$ dan komitmen afektif (AFC) $X_{3}$ serta dampaknya pada Organizational Citizenship Behavior (OCB) Y Pegawai Badan Penelitian dan Pengembangan, Pendidikan dan Pelatihan dan Informasi Kementerian Desa, Pembangunan Daerah Tertinggal dan Transmigrasi Jakarta. Penelitian ini menggunakan model persamaan SEM (Structural Equational Modeling) untuk menguji hubungan/pengaruh antar variabel. Adapun populasi dalam penelitian ini sebanyak 160 orang.

Hasil penelitian ini adalah sebagai berikut : Persepsi Dukungan Organisasi berpengaruh positif dan signifikan terhadap kepuasan kerja pegawai, besarnya pengaruh langsung sebesar 34.81\%. Persepsi Dukungan Organisasi berpengaruh terhadap komitmen afektif pegawai, besarnya pengaruh langsung sebesar $14.44 \%$. Kepuasan kerja berpengaruh terhadap komitmen afektif pegawai, besarnya pengaruh langsung sebesar $20.25 \%$. Persepsi Dukungan Organisasi berpengaruh terhadap Organizational Citizenship Behavior pegawai, besarnya pengaruh langsung sebesar 5.76\%. Kepuasan kerja berpengaruh terhadap Organizational Citizenship Behavior pegawai, besarnya pengaruh langsung sebesar $9.61 \%$. Komitmen afektif berpengaruh terhadap Organizational Citizenship Behavior pegawai, besarnya pengaruh langsung sebesar $6.25 \%$. 


\section{PENDAHULUAN \\ Latar Belakang}

Menurut Titisari (2014, hlm.3 \& 5) disebutkan bahwa Organizational Citizenship Behavior (OCB) membantu mengubah suasana organisasi yang formal menjadi sedikit santai dan penuh dengan kerja sama. Diharapkan dengan suasana yang seperti itu maka ketegangan diantara para karyawan dapat dikurangi dan arena suasana yang mendukung diharapkan produktivitas karyawan meningkat, sehingga akan tercapai keefektifan dan keefisienan. Selanjutnya juga disebutkan bahwa Organizational Zitizenship Behavior (OCB) merupakan kontribusi individu yang melebihi tuntutan peran di tempat kerja. Organizational Zitizenship Behavior (OCB) ini melibatkan beberapa perilaku meliputi perilaku menolong orang lain, menjadi volunteer untuk tugas-tugas ekstra, patuh terhadap aturan-aturan dan prosedur-prosedur di tempat kerja. Perilaku-perilaku in menggambarkan "nilai tambah karyawan" yang merupakan salah satu bentuk perilaku prososial, yaitu perilaku social yang positif, konstruktif dan bermakna membantu.

Perilaku kewargaan organisasi datang dalam berbagai bentuk seperti kesetiaan, membantu orang lain, dan kepatuhan organisasi (Podsakoff et al., 2009) dan organisasi menguntungkan karyawan yang bersedia untuk berkontribusi upaya dan kemampuan mereka untuk organisasi meskipun itu tidak secara resmi diperlukan dari mereka. Kontribusi dari perilaku kewargaan organisasional untuk organisasi telah menerima banyak perhatian di dunia bisnis (Lee, Kim dan Kim, 2013, 56). Konsep perilaku kewargaan organisasional muncul lebih dari dua dekade yang lalu di bidang perilaku organisasi. Sejak itu, banyak penelitian terutama di Amerika Serikat yang memungkinkan beragam pemahaman dan interpretasi dari konsep ini (Lee, Kim dan Kim, 2013,57 ).

Beberapa riset terkini yang mengetengahkan masalah OCB antara lain Lee, Kim dan Kim (2013) yang menggunakan faktor keadilan prosedural, kepemimpinan transformasional, dan kompleksitas memiliki efek positif pada OCB karyawan dan OCB juga berhubungan positif dengan kepuasan kerja. Piercy, dkk (2006); Liu (2009); Williams, Pitre, Zainuba, (2002) menggunakan manajemen kontrol, keadilan dan persepsi dukungan organisasi, Chen dan Chiu (2009) menggunakan karakteristik pekerjaan; Alizadeh, (2010) menggunakan budaya organisasi sebagai predictor OCB, Qamar (2012) menggunakan komitmen dan kepuasan kerja sebagai anteseden OCB.

Ketertarikan meneliti masalah OCB didasarkan pada pertimbangan pentingnya OCB dalam mempengaruhi efektivitas dan efisiensi kerja tim dan organisasi, sehingga berkontribusi terhadap produktivitas organisasi secara menyeluruh (Sharma, dkk, 2011,68). Selain pertimbangan tersebut, hasil pengamatan di lapangan menunjukkan relatif rendahnya OCB pegawai yang dapat dilihat dari kurangnya perilaku saling membantu antar pegawai maupun antar bagian, kurangnya kepedulian pegawai pada kinerja organisasi secara umum atau kinerja tim secara khusus, masih adanya beberapa pegawai yang mengeluh mengenai pekerjaan dan berbagai perilaku lain yang menunjukkan masih belum maksimalnya periaku kewargaan organisasi pegawai. Berdasarkan penelaahan litelatur, beberapa faktor yang diduga relevan terkait dengan OCB ini adalah persepsi dukungan organisasi, kepuasan kerja dan komitmen afektif pegawai. 
Dukungan organisasi yang dirasakan (perceived organizational support / (POS) merupakan keyakinan karyawan bahwa organisasi peduli dan menghargai kontribusinya terhadap keberhasilan organisasi. Anteseden POS mencakup keadilan prosedural, tindakan mendukung dan hormat oleh supervisor, pengakuan, gaji yang adil dan penghargaan, promosi, keamanan kerja, otonomi, dan pelatihan (Peelle, 2007, 555). Konsekuensi POS tinggi meningkat komitmen organisasi, kepuasan kerja, berdampak positif, kinerja tugas, dan niat untuk tetap dengan organisasi (Peelle, 2007, 556). Terkait dengan POS, hasil pengamatan di lapangan masih menunjukkan relatif rendahnya dukungan organisasi dalam bentuk kebijakan untuk meningkatkan kesejahteraan dan perasaan prestasi, dukungan karir, dan kontribusi positif terhadap organisasi, dan pribadi dan pencapaian tujuan organisasi.

Melalui hasil pengamatan juga diketahui bahwa banyak pegawai dalam bekerja jarang sekali akan membantu rekannya walaupun pekerjaan yang dikerjakannya sudah selesai, karena mereka beranggapan bahwa pekerjaan orang lain adalah bukan tanggung jawabnya. Kondisi tersebut didukung dengan belum adanya pemerataan bagi pegawai untuk mengikuti pendidikan dan pelatihan, yang mengakibatkan rendahnya kepuasan kerja.

Rendahnya dukungan organisasional yang dirasakan selanjutnya memicu rendahnya kepuasan kerja pegawai. Kepuasan ini dalam konteks ini adalah perasaan positif pegawai pada hal-hal yang terkait dengan pekerjaan. Selain merupakan dampak dari rendahnya POS pegawai, kepuasan kerja juga diyakini sebagai faktor yang mempengaruhi OCB pegawai. Beberapa riset seperti Miao (2011); Lee, Kim dan Kim (2013) menemukan efek positif kepuasan kerja terhadap OCB karyawan. Meskipun secara intensif sudah diteliti, hubungan antara kepuasan kerja dan OCB masih menunjukkan beberapa gap seperti penelitian menunjukkan bahwa kepuasan kerja merupakan prediktor lemah OCB dan hanya memiliki pengaruh parsial dalam menentukan Courtesy dan Altruisme pada dimensi OCB (Farhan Mehboob dan Niaz A Bhutto, 2012); sedangkan Qamar, Nida. (2012) menemukan hubungan antara kepuasan kerja dengan OCB dalam level moderat. Faktor lainnya adalah komitmen afektif yang merupakan ikatan emosional karyawan untuk organisasi mereka, telah diakui sebagai anteseden efektif dari OCB dalam organisasi mereka (Meyer, Stanley, Herscovitch, \& Topolnytsky, 2002).

Terkait dengan komitmen, OCB dan kepuasan kerja, beberapa penelitian memiliki perbedaan yang cukup mendasar sehingga menarik untuk diteliti ulang. Seperti penelitian Setyawan (2009); yang memasukkan OCB sebagai intervening pada hubungan antara kepuasan dan komitmen dan menempatkan komitmen sebagai faktor yang mempengaruhi kepuasan kerja (Lee, Kim dan Kim, 2013). Konsep ini berbeda dengan penelitian Rahmi (2013) yang menempatkan kepuasan kerja sebagai faktor yang mempengaruhi komitmen dan OCB, dan penelitian Liu (2008) yang menempatkan komitmen afektif sebagai mediator pada hubungan dukungan organisasional dengan OCB. Perbedaan lain juga dapat dilihat dari penelitian Sharma, dkk (2011) yang menempatkan OCB sebagai faktor yang mempengaruhi kepuasan kerja. Qamar (2013) dalam risetnya menempatkan kepuasan kerja dan komitmen sebagai faktor yang mempengaruhi OCB, sedangkan Chahal dan Mehta (2011) 
menempatkan OCB sebagai faktor yang mempengaruhi kepuasan kerja, yang berbeda dengan Ren-Tao Miao (2011); Liu (2008); Podsakoff, dkk (2000).

Berdasarkan uraian diatas, penelitian ini bertujuan untuk mengetahui pengaruh antara dukungan organisasi yang dirasakan (POS), kepuasan kerja (SAT), komitmen afektif dan organizational citizenship behavior (OCB) pegawai di Badan penelitian, Pengembangan dan informasi, Kementerian Tenaga Kerja dan Transmigrasi di Jakarta.

\section{Rumusan Masalah}

Berdasarkan latar belakang diatas, maka rumusan masalah dalam penelitian ini adalah sebagai berikut.

a. Apakah persepsi dukungan organisasi berpengaruh terhadap kepuasan kerja, komitmen afektif pegawai dan OCB Pegawai?

b. Apakah kepuasan kerja berpengaruh terhadap komitmen afektif pegawai dan OCB Pegawai.

c. Apakah komitmen afektif berpengaruh terhadap OCB pegawai.

\section{Tujuan Penelitian}

Penelitian ini bertujuan untuk mengetahui apakah:

a. Persepsi dukungan organisasi berpengaruh terhadap kepuasan kerja, komitmen afektif pegawai dan OCB pegawai.

b. Kepuasan kerja berpengaruh terhadap komitmen afektif pegawai dan OCB Pegawai.

c. Komitmen afektif berpengaruh terhadap OCB pegawai.

\section{KAJIAN PUSTAKA}

\section{Perilaku Kewargaan Organisasi / Organizational Citizenship Behavior (OCB)}

Istilah Organizational citizenship behavior (OCB) menurut Budiharjo (2011, 139) pertama kali diperkenalkan oleh Organ di tahun 1980-an. Organizational Citizenship Behavior (OCB) didefinisikan sebagai "kinerja yang mendukung lingkungan sosial dan psikologis dimana kinerja tugas berlangsung". OCB sangat penting untuk sebuah organisasi yang efektif karena meliputi perilaku yang tidak secara langsung berhubungan dengan tugas kinerja tetapi penting untuk keseluruhan kinerja organisasi (Zheng, Zhang dan Hai, 2012, 734). $O C B$ adalah upaya ekstra karyawan yang tidak diperlukan secara resmi oleh organisasi dan tindakan diskresi oleh karyawan. Dua komponen utama dari OCB adalah kepatuhan, yang menunjukkan niat untuk mengikuti aturan organisasi, dan altruisme, yang berarti karyawan berperilaku sukarela untuk membantu orang lain dan bekerja (Lee, dkk, 2013, 2).

Secara singkat, Budiharjo (2011, hlm. 140) mendefinisikan OCB sebagai perilaku sukarela individu (dalam hal ini adalah karyawan) yang tidak secara langsung berkaitan dengan pengimbalan, namun berkontribusi pada keefektivan organisasi. Dengan kata lain, OCB merupakan perilaku seseorang karyawan bukan karena tuntutan tugasnya namun lebih kepada kesukarelaannya. Azizollah, dkk (2014, hlm. 52) mengutip pendapat Crede, dkk (2007) menyebutkan bahwa OCB merujuk pada perilaku yang dimaksudkan untuk membantu rekan kerja, supervisor atau organisasi dan mencakup tindakan seperti membantu rekan kerja, mencoba untuk meningkatkan semangat kerja, menjadi relawan untuk pekerjaan yang bukan merupakan bagian dari 
deskripsi pekerjaan, berbicara positif tentang organisasi kepada orang luar serta menyarankan perbaikan dalam fungsi organisasi.

Dari uraian diatas maka penelitian ini mendefiniskan Organizational Citizenship Behavior (OCB) sebagai bentuk kontribusi individu ditempat kerja yang dilakukan diluar tugas pokok dan secara sukarela. Perilaku ini dapat berbentuk seperti menolong orang lain, aktif dalam kegiatan kantor, bertindak sesuai prosedur dan memberikan pelayanan kepada semua orang yang dapat meningkatkan efektivitas dan efisiensi kerja organisasi.

\section{Persepsi Dukungan Organisasi / Perceived Organizational Support (POS)}

POS mencerminkan kualitas hubungan karyawan-organisasi dengan mengukur sejauh mana karyawan percaya bahwa organisasi mereka menghargai kontribusi mereka dan peduli tentang kesejahteraan mereka. Karyawan mengembangkan POS melalui penilaian kondisi mereka bekerja, penghargaan organisasi, dukungan yang diterima dari supervisor, dan keadilan procedural (Liu, 2009, 309). Lebih lanjut, POS didefinisikan sebagai keyakinan global yang karyawan tentang sejauh mana organisasi peduli tentang kesejahteraan mereka dan menghargai kontribusi mereka (Wang, dkk, 2014,1070). POS pada dasarnya berarti pengakuan oleh organisasi dalam bentuk kebutuhan individu sosio-emosional, upaya, komitmen dan loyalitas (Jain, Giga dan Cooper, 2013, 315). Duffy dan Lilly $(2013,186)$ memberikan definisi POS pada keyakinan pekerja dalam berapa banyak organisasi menghargai kontribusi mereka dan peduli tentang kesejahteraan mereka.

Menurut teori dukungan organisasi, POS tinggi cenderung untuk meningkatkan sikap kerja dan menimbulkan perilaku kerja yang efektif selama dua tahap. Pertama, POS memiliki efek menguntungkan ini hasil dari proses pertukaran sosial. Jika sebuah organisasi diberi pelatihan yang memadai, sumberdaya dan dukungan dari manajemen, hal ini mungkin bahwa para anggota akan sama-sama ingin organisasi mereka untuk berhasil dan menjadi lebih mampu membantu organisasi mereka berhasil. Oleh karena itu, muncul kemungkinan bahwa sejauh mana organisasi merasakan bahwa hal itu didukung akan berhubungan positif dengan OCB (Eisenberger, Armeli, Rexwinkel, Lynch, \& Rhoades, 2001; Wayne, Shore, Bommer, \& Tetrick, 2002, dalam Ren-Tao Miao, 2011, 108-109).

Berdasarkan uraian diatas, maka penulis menyimpulkan bahwa persepsi dukungan organiasi merupakan keyakinan pegawai mengenai sejauh mana organisasi menghargai kontribusi dan memperdulikan kesejahteraan mereka.

\section{Kepuasan Kerja / Work Satisfaction}

Luthan (2010, hlm.126) merumuskan kepuasan kerja adalah suatu keadaan emosi seseorang yang positif maupun menyenangkan yang dihasilkan dari penilaian suatu pekerjaan dan pengalaman kerja. Kepuasan kerja mencerminkan perasaan seseorang terhadap pekerjaannya. Hal ini tampak dalam sikap positif karyawan terhadap pekerjaan dan segala sesuatu yang dihadapi lingkungan kerjanya. Robbins dan Coulters (2010) berpendapat kepuasan kerja adalah suatu sikap umum (general 
attitude) dari pegawai terhadap pekerjaan yang dikerjakan. Ketika membicarakan tentang sikap pegawai (employee attitude), hal-hal yang dibicarakan biasanya merujuk pada kepuasan kerja artinya bahwa kepuasan kerja atau ketidak-puasan kerja adalah corak sikap dari pegawai terhadap pekerjaan yang ia kerjakan.

Kepuasan kerja mengacu pada arti keseluruhan kesejahteraan karyawan di tempat kerja. Ini adalah state internal berdasarkan penilaian pekerjaan dan pengalaman yang berhubungan dengan pekerjaan dengan beberapa derajat mendukung atau tidak disukai (Locke, 1976, dalam Ren-Tao Miao, 2011, 109). Kepuasan kerja adalah konsep multi-dimensi yang memperhitungkan bagaimana orang merasa tentang isi pekerjaan mereka dan konteks di mana pekerjaan mereka dilakukan termasuk dimensi seperti tingkat gaji, keamanan kerja, dan fleksibilitas jadwal. Selain itu, kepuasan kerja merupakan kontributor kunci untuk berbagai kesehatan dan hasil kinerja yang berhubungan, seperti karyawan kesejahteraan psikologis dan produktivitas.

Berdasarkan definisi diatas maka penelitian ini menyimpulkan bahwa kepuasan kerja adalah suatu perasaan emosi positif atau negatif yang berhubungan dengan pekerjaannya maupun dengan kondisi dirinya. Perasaan yang berhubungan dengan pekerjaan melibatkan aspek-aspek seperti upah atau gaji yang diterima, kesempatan pengembangan karir, hubungan dengan pegawai lainnya, penempatan kerja, jenis pekerjaan, struktur organisasi perusahaan, mutu pengawasan sedangkan perasaan yang berhubungan dengan dirinya, antara lain umur, kondisi kesehatan, kemampuan, pendidikan. Pegawai akan merasa puas dalam bekerja apabila aspek-aspek pekerjaan dan aspek-aspek dirinya menyokong dan sebaliknya jika aspek-aspek tersebut tidak menyokong, pegawai akan merasa tidak puas.

\section{Komitmen Afektif / Affective Commitment}

Menurut Sabir, dkk (2011) disebutkan bahwa komitmen organisasi dapat dibedakan dalam tiga jenis, masing-masing komitmen tersebut memiliki tingkat atau derajat yang berbeda. Ketiga jenis komitmen organisasi tersebut adalah: (1) Continuance Commitment (komitmen kontinuan/rasional), bearti komitmen berdasarkan persepsi anggota tentang kerugian yang akan dihadapinya jika meninggalkan organisasi yaitu seorang anggota tetap bertahan atau meninggalkan organisasi berdasarkan pertimbangan untung rugi yang diperolehnya; (2) Normative Commitment (komitmen normatif) merupakan komitmen yang meliputi perasaanperasaan individu tentang kewajiban dan tanggung jawab yang harus diberikan kepada organisasi, sehingga individu tetap tinggal di organisasi karena wajib untukloyal terhadap organisasi; (3) Affective Commitment (komitmen afektif) berkaitan dengan emosional, identitifikasi dan keterlibatan individu di dalam suatu organisasi, anggota yang mempunyai komitmen ini mempunyai keterikatan emosional terhadap organisasi yang tercermin melalui keterlibatan dan perasaan senang serta menikmati perannya dalam organisasi.

Sabir, dkk (2011) dalam penelitiannya juga menambahkan bahwa komitmen afektif menunjukkan tingkat keterikatan karyawan dengan organisasi termasuk keyakinan, kemauan, dan keinginan tentang prestasi tujuan organisasi yang memiliki hubungan erat dengan karakteristik pribadi, usia,jenis kelamin, jabatan, dan karakteristik organisasi. Menurut Cut Zurnali (2010), hal menarik dalam pengertian 
komitmen organisasi bahwa komitmen organisasi merupakan perasaan yang kuat dan erat dari seorang terhadap tujuan dan nilai suatu organisasi dalam hubungannya dengan peran mereka terhadap upaya pencapaian tujuan dan nilai-nilai tersebut. Komitmen organisasional sebagai sebuah keadaan psikologi yang mengkarakteristikkan hubungan karyawan dengan organisasi atau implikasinya yang mempengaruhi apakah karyawan akan tetap bertahan dalam organisasi atau tidak, yang teridentifikasi dalam tiga komponen yaitu: (1) Komitmen afektif (affective commitment); (2) Komitmen kontinyu (continuance commitment); dan (3) Komitmen normative (normative commitment).

Dari berbagai pendapat para ahli tersebut penulis mendefinisikan komitmen afektif dalam organisasi adalah perasaan cinta pada organisasi yang memunculkan kemauan untuk tetap tinggal dan membina hubungan social serta menghargai nilai hubungan dengan organisasi dikarenakan telah menjadi anggota organisasi.

\section{METODE PENELITIAN}

\section{Tempat dan Waktu Penelitian}

Penelitian ini dilakukan di Kementerian Tenaga Kerja dan Transmigrasi pada Unit di Badan Penelitian Pengembangan dan Informasi (Balifo) yang beralamat di Jalan Taman Makam Pahlawan Kalibata No. 17 Jakarta Selatan. Waktu penelitian dilaksanakan dari bulan Januari - Juli 2017.

\section{Populasi dan Sampel}

Objek analisis yang diteliti sebagai populasi dalam penelitian ini seluruh pegawai di Badan Penelitian, Pengembangan dan Informasi, Kemenakertrans Jakarta. Ukuran sampel penelitian didasarkan pada pertimbangan ukuran sampel minimal untuk analisis SEM yaitu 5 x jumlah indikator (Hair, dkk, 2014). Karena indikator berjumlah 29, maka sampel minimal penelitian ini adalah sebesar 145 yang diambil secara acak di empat bagian yaitu Puslitbangnaker, Puslitbangtrans, Pusdatinaker, dan Pusdatintrans dan Sekretariat. Untuk mengantisipasi adanya kuesioner yang tidak kembali, maka ukuran sampel ditambah 10\% dari sampel minimal sehingga berjumlah 160 .

\section{Jenis dan Sumber Data}

Sumber data dalam penelitian ini adalah data primer, yaitu di peroleh dari penyebaran kuesioner/angket yang di jawab oleh pegawai.

\section{Teknik Pengumpulan Data}

Instrumen yang digunakan dalam penelitian ini berbentuk angket, dengan jumlah variabel sebanyak 4 variabel yaitu Persepsi Dukungan Organisasi (POS), Kepuasan Kerja (SAT), Komitmen Afektif (AFC), dan Perilaku Kewarganegaraan Organisasional (OCB), dengan menggunakan Skala Likert dalam pengukuran jawaban dari para responden.

\section{Metode dan Teknik Analisis Data}

Metode analisis yang dipilih yang dipilih dalam penelitian ini untuk menganalisis data adalah dengan menggunakan SEM (Structural Equation Model), yang dioperasikan melalui program LISREL. Model persamaan structural, Structural 
Equation Model (SEM) adalah sekumpulan teknik - teknik statistical yang memungkinkan pengujian sebuah rangkaian hubungan relatif "rumit" secara simultan. Untuk membuat permodelan yang lengkap beberapa langkah yang perlu dilakukan yaitu membuat spesifikasi model : tahapan ini terkait dengan pembentukan model awal persamaan struktural, sebelum dilakukannya estimasi. Model awal diformulasikan berdasarkan suatu teori atau penelitian-penelitian sebelumnya.

Tabel 1. Model Struktural

\begin{tabular}{|l|l|l|}
\hline No & Model & Persamaan \\
\hline 1 & $\mathrm{SAT}$ & $\mathrm{SAT}=\gamma_{1} \mathrm{POS}+\zeta_{1}$ \\
\hline 2 & $\mathrm{ACC}$ & $\mathrm{ACC}=\gamma_{2} \mathrm{POS}+\beta_{1} \mathrm{SAT}+\zeta_{2}$ \\
\hline 3 & $\mathrm{OCB}$ & $\mathrm{SAT}=\gamma_{3} \mathrm{POS}+\beta_{2} \mathrm{SAT}+\gamma_{3} \mathrm{ACC}+\zeta_{3}$ \\
\hline
\end{tabular}

Keterangan :

$\gamma($ GAMMA $)=$ koefisien jalur variabel laten eksogen ke endogen

$\beta($ BETA $)=$ koefisien jalur variabel laten endogen ke endogen

$\zeta($ ZETA $)=$ residual error dalam persamaan structural

$\delta($ DELTA $)=$ kesalahan pengukuran variabel eksogen

$\varepsilon($ EPILSON $)=$ Kesalahan pengukuran variabel endogen

\section{HASIL PENELITIAN DAN PEMBAHASAN}

Analisis hasil pengolahan data pada tahap full model SEM dilakukan dengan melakukan uji kesesuaian dan uji statistik. Analisis model struktural menggunakan metode maximum likelihood (MLE). Hasil estimasi model structural dengan seluruh metode estimasi selanjutnya dijelaskan berikut ini :

Tabel 2. Goodness Of Fit Index (GOFI) Model Struktural

\begin{tabular}{|l|l|l|l|}
\hline GOFI & Nilai Awal & Nilai Standar & Kesimpulan \\
\hline p value $\chi^{2}$ & 0.000 & P value $\geq 0.05$ & Kurang Baik \\
\hline RMSEA & 0.058 & RMSEA $\leq 0,08$ & Good fit \\
\hline NFI & 0.973 & NFI $\geq 0,90$ & Good fit \\
\hline NNFI & 0.976 & NNFI $\geq 0,90$ & Good fit \\
\hline CFI & 0.976 & CFI $\geq 0,90$ & Good fit \\
\hline GFI & 0.977 & GFI $\geq 0,90$ & Goof fit \\
\hline
\end{tabular}

Sumber : Hasil Penelitian, diolah (2017)

Berdasarkan evaluasi atas kecocokan model seperti tampilan tabel di atas terlihat bahwa indeks kecocokan absolute meliputi $\mathrm{p}$ value, RMSEA, GFI, dua diantaranya memenuhi kecocokan data yaitu GFI dan RMSEA. Sedangkan nilai $p$ value chi-square sebesar 0.000 (kurang baik) menunjukkan Kecocokan yang kurang baik. Indeks kecocokan incremental yang terdiri dari CFI, NFI, NNFI, AGFI, RFI, dan IFI, seluruhnya memiliki memiliki kecocokan baik (nilai > 0.90) kecuali AGFI yang berada pada tingkat marginal fit. Memperhatikan temuan ini, maka dapat dinyatakan bahwa secara mayoritas evaluasi indeks-indeks kecocokan model sudah memenuhi kriteria goodness of fit.

Parameter uji hipotesis menggunakan perbandingan nilai $t$, yaitu jika nilai $t$ hitung $>$ dari $\mathrm{t}$ table (1.96), maka $\mathrm{H}_{0}$ ditolak dan $\mathrm{H}_{1}$ diterima. Rangkuman hasil pengujian hipotesis selanjutnya dirangkum dalam tabel berikut ini : 
Tabel 3. Persamaan Struktural

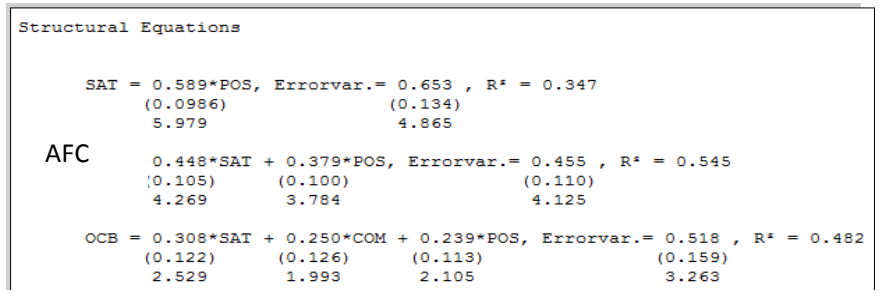

Sumber : Hasil Penelitian, diolah (2017)

Gambar 1. Diagram Lintasan Model Struktural (Standardized Solution)

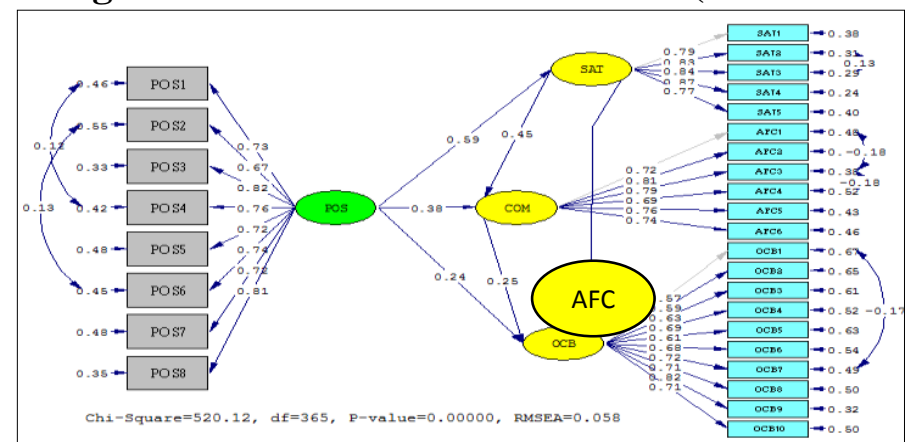

Sumber : Hasil Penelitian, diolah (2017)

Gambar 2. Uji t Model Struktural

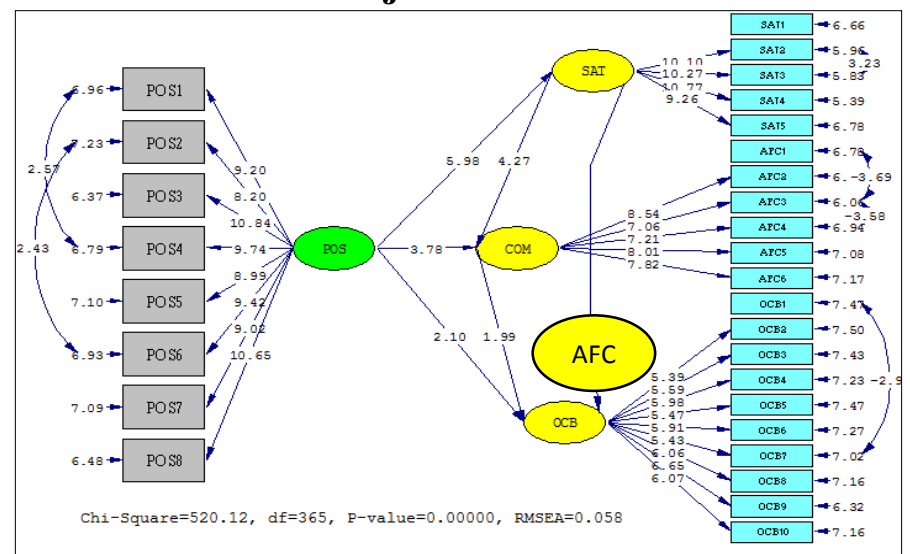

Sumber : Hasil Penelitian, diolah (2017)

Penelitian ini berhasil membuktikan tiga persamaan struktural yang menempatkan kepuasan kerja sebagai variable endogen pada struktural pertama, komitmen organisasi sebagai endogen pada struktural kedua, dan OCB ditempatkan sebagai endogen pada structural ketiga. Melalui persamaan structural diperoleh nilai $\mathrm{R}^{2}$ $=0,347$ untuk persamaan struktural pertama. Nilai ini merupakan representasi kemampuan POS menjelaskan variasi kepuasan kerja sebesar $34.70 \%$ dan sisanya $65.30 \%$ dipengaruh factor lain di luar model.

Nilai $\mathrm{R}^{2}=0.545$ untuk structural kedua mengindikasikan kemampuan model yaitu POS dan kepuasan kerja menjelaskan variasi komitmen afektif sebesar $54.50 \%$, dan sisanya $45.50 \%$ dipengaruh factor lain di luar model. Terakhir adalah nilai $\mathrm{R}^{2}=$ 0.482 untuk structural ketiga merupakan representasi kemampuan POS, kepuasan kerja 
dan komitmen afektif menjelaskan variasi OCB sebesar $48.20 \%$, dan sisanya $51.80 \%$ dipengaruh factor lain di luar model.

Uraian masing-masing jalur hubungan pada model structural dijelaskan sebagai berikut:

Persepsi Dukungan Organisasi berpengaruh terhadap kepuasan kerja pegawai Badan Penelitan dan Pengembangan, Pendidikan dan Pelatihan, dan Informasi.

Berdasarkan hasil penelitian berhasil dibuktikan adanya pengaruh positif dan signifikan dukungan organisasi terhadap kepuasan kerja. Pengaruh langsung persepsi dukungan organisasi terhadap kepuasan kerja berdasarkan nilai koefisien standard adalah sebesar 0,59 dan $\mathrm{t}$ hitung sebesar 5.98, atau naik turunnya kepuasan kerja mampu dijelaskan oleh POS sebesar $34.81 \%\left(0,59^{2}\right.$ x $\left.100 \%\right)$, sedangkan sisanya $65.19 \%$ (100\%-34.81\%) dipengaruh faktor lain. Dapat dinyatakan bahwa semakin tinggi persepsi dukungan organisasi yang dirasakan oleh pegawai di Badan Penelitan dan Pengembangan, Pendidikan dan Pelatihan, dan Informasi akan berimplikasi pada tingginya kepuasan kerja pegawai.

Berdasarkan koefisien bobot faktor ditemukan bahwa keluhan (POS3) merupakan indikator POS yang memiliki memiliki koefisien tertinggi yaitu 0.817 , kemudian kebanggan organisasi (POS8) dengan koefisien bobot faktor 0.808, POS4 yaitu kepedulian organisasi pada kesejahteraan pegawai sebesar 0.761. Indikator POS6 yaitu kepedulian organisasi pada kepuasan umum pegawai berada di urutan ke-4 dengan koefisien bobot faktor sebesar 0.744, POS7 yaitu perhatian organisasi (0.720), POS5 yaitu perhatian pada hasil kerja (0.718), dan terakhir adalah POS2 yaitu penghargaan atas usaha esktra (0.672). Hal ini mencerminkan bahwa indikator perhatian pada keluhan pegawai, kebanggaan organisasi, dan kepedulian organisasi merupakan tiga indikator yang paling representative dalam menjelaskan persepsi dukungan organisasi.

\section{Persepsi Dukungan Organisasi berpengaruh terhadap komitmen afektif pegawai Badan Penelitan dan Pengembangan, Pendidikan dan Pelatihan, dan Informasi.}

Berdasarkan hasil penelitian berhasil dibuktikan adanya pengaruh positif dukungan organisasi terhadap komitmen afektif. Pengaruh langsung persepsi dukungan organisasi terhadap komitmen afektif berdasarkan nilai koefisien standard adalah sebesar 0,38 dan t hitung sebesar 3.78, atau naik turunnya komitmen afektif mampu dijelaskan oleh POS sebesar $14.44 \%\left(0,38^{2} \times 100 \%\right)$, sedangkan sisanya $85.56 \%$ (100\%-14.44\%) dipengaruh faktor lain. Dapat dinyatakan bahwa semakin tinggi persepsi dukungan organisasi yang dirasakan oleh pegawai di Badan Penelitan dan Pengembangan, Pendidikan dan Pelatihan, dan Informasi akan berimplikasi pada tingginya komitmen afektif pegawai.

Berdasarkan koefisien bobot faktor ditemukan bahwa keluhan (POS3) merupakan indikator POS yang memiliki memiliki koefisien tertinggi yaitu 0.817 , kemudian kebanggaan organisasi (POS8) dengan koefisien bobot faktor 0.808, POS4 yaitu kepedulian organisasi pada kesejahteraan pegawai sebesar 0.761. Indikator POS6 yaitu kepedulian organisais pada kepuasan umum pegawai berada di urutan ke-4 dengan koefisien bobot faktor sebesar 0.744, POS7 yaitu perhatian organisasi (0.720), POS5 yaitu perhatian pada hasil kerja $(0.718)$, dan terakhir adalah POS2 yaitu 
penghargaan atas usaha esktra (0.672). Hal ini mencerminkan bahwa indikator perhatian pada keluhan pegawai, kebanggaan organisasi, dan kepedulian organisasi merupakan tiga indikator yang paling representative dalam menjelaskan persepsi dukungan organisasi.

Implikasi temuan ini organisasi perlu mempertahankan perhatian pada keluhan pegawai, kebanggan organisasi, dan kepedulian organisasi, dan meningkatkan penghargaan atas usaha ekstra pegawai. Selain itu, perlu memberikan perhatian pada hasil kerja pegawai karena teridentifikasi sebagai indikator yang memiliki koefisien bobot faktor terendah.

\section{Kepuasan kerja berpengaruh terhadap komitmen afektif pegawai Badan Penelitan dan Pengembangan, Pendidikan dan Pelatihan dan Informasi..}

Berdasarkan hasil penelitian berhasil dibuktikan adanya pengaruh positif kepuasan kerja terhadap komitmen. Koefisien jalur pengaruh kepuasan kerja terhadap komitmen menunjukkan nilai koefisien standard sebesar 0.45 dan t hitung sebesar 4.27. Nilai standardized diperoleh sebesar 0.45 ini mengindikasikan kemampuan kepuasan kerja menjelaskan komitmen afektif adalah sebesar 20.25 dan sisanya $79.75 \%$ dipengaruhi faktor lain di luar mode.

Berdasarkan koefisien bobot factor diketahui bahwa indicator SAT4 (perlakukan yang adil) merupakan indicator yang paling dominan dengan koefisien bobot factor sebesar 0.874, kemudian SAT3 yaitu hubungan dengan rekan (0.844) dan SAT2 (cara atasan menangani bawahan) sebesar 0.833. Indikator terendah adalah SAT5 yaitu kompetensi supervisor dan SAT1 yaitu pekerjaan yang menarik (0.787).

Implikasi temuan ini adalah dalam upaya meningkatkan komitmen afektif melalui kepuasan kerja ini harus dilakukan upaya meningkatkan kompetensi supervisor dan memberikan pekerjaan yang menarik karena terbukti kedua indikator ini memiliki bobot faktor terendah. Kemudian untuk indikator yang sudah baik yaitu perlakuan adil dan hubungan baik dengan sesame rekan harus terus dipertahankan untuk menjaga komitmen afektif pegawai.

Pimpinan Badan Penelitan dan Pengembangan, Pendidikan dan Pelatihan, dan Informasi sebaiknya melakukan supervisi yang memadai khususnya yang berhubungan dengan tugas dan pekerjaan pegawai yang harus diselesaikan. Supervisi yang dilakukan harus memperhatikan tugas, tanggungjawab dan wewenang yang dimiliki pegawai dengan tujuan supervisi yang dilakukan tidak mengganggu wewenang (seperti: pengambilan keputusan) yang dapat diambil oleh pegawai. Hal ini dilakukan dengan tujuan agar pegawai memiliki kebebasan menjalankan tugas dan kewajibannya dengan lebih baik.

Kemudian untuk indikator yang sudah baik yaitu perlakuan adil dan hubungan baik dengan sesama rekan harus terus dipertahankan untuk menjaga komitmen afektif pegawai. Upaya yang dapat dilakukan oleh pimpinan Badan Penelitan dan Pengembangan, Pendidikan dan Pelatihan, dan Informasi adalah dengan memberdayakan pegawai yang pada dasarnya membentuk pegawai yang berkomitmen. Pemberdayaan pegawai berangkat dari keinginan untuk menggali seluruh potensi yang terdapat dalam diri seluruh pegawai untuk diarahkan dalarn memajukan organisasi. Untuk menjadikan pegawai yang memiliki kompetensi memadai sangat ditentukan 
oleh kualitas lingkungan kerja kondusif yang dibangun di dalam organisasi. Lingkungan kerja yang kondusif, yaitu : terdapat kepercayaan timbal balik (mutual trust) antara pimpinan dengan pegawai, terdapat komitmen pegawai terhadap misi, visi, core beliefs dan core values organisasi, kesediaan pimpinan untuk memberikan wewenang kepada bawahan untuk mengambil keputusan atas pekerjaan yang menjadi tanggung jawab bawahan, perlakuan adil, hubungan baik dengan sesama rekan, dan menciptakan pekerjaan yang menarik dan penuh tantangan kepada pegawai.

Persepsi Dukungan Organisasi berpengaruh terhadap Organizational Citizenship Behavior pegawai Badan Penelitian dan Pengembangan, Pendidikan dan Pelatihan, dan Informasi.

Berdasarkan hasil penelitian berhasil dibuktikan adanya pengaruh positif dukungan organisasi terhadap OCB. Pengaruh langsung persepsi dukungan organisasi terhadap OCB berdasarkan nilai koefisien standard adalah sebesar 0,24 dan t hitung sebesar 2.10, atau naik turunnya OCB mampu dijelaskan oleh POS sebesar $5.76 \%$ $\left(0,24^{2} \times 100 \%\right)$, sedangkan sisanya $94.24 \%$ (100\%-5.76\%) dipengaruhi faktor lain. Dapat dinyatakan bahwa semakin tinggi persepsi dukungan organisasi yang dirasakan oleh pegawai di Badan Penelitan dan Pengembangan, Pendidikan dan Pelatihan, dan Informasi akan berimplikasi pada tingginya OCB pegawai.

Berdasarkan koefisien bobot faktor diketahui bahwa perhatian pada keluhan pegawai, kebanggan organisasi, dan kepedulian organisasi merupakan tiga indikator yang paling representative dalam menjelaskan persepsi dukungan organisasi. Dengan demikian, implikasi temuan ini organisasi perlu mempertahankan perhatian pada keluhan pegawai, kebanggan organisasi, dan kepedulian organisasi, dan meningkatkan penghargaan atas usaha ekstra pegawai. Selain itu, perlu memberikan perhatian pada hasil kerja pegawai karena teridentifikasi sebagai indikator yang memiliki koefisien bobot faktor terendah.

\section{Kepuasan kerja berpengaruh terhadap Organizational Citizenship Behavior pegawai Badan Penelitan dan Pengembangan, Pendidikan dan Pelatihan, dan Informasi. \\ Berdasarkan hasil penelitian berhasil dibuktikan adanya pengaruh positif} kepuasan kerja terhadap OCB. Koefisien jalur pengaruh kepuasan kerja terhadap OCB menunjukkan nilai koefisien standard sebesar 0.31 dan t hitung sebesar 2.53. Nilai standardized diperoleh sebesar 0.31 ini mengindikasikan kemampuan kepuasan kerja menjelaskan OCB adalah sebesar 9.61 dan sisanya $90.39 \%$ dipengaruhi faktor lain di luar model. OCB dianggap sarana yang seorang karyawan dapat memberikan kembali kepada organisasi, sehingga, jika seorang karyawan puas dengan pekerjaannya, karyawan mungkin lebih cenderung untuk membalas dengan membantu orang lain melalui perilaku kewarganegaraan mereka. Karyawan mungkin kurang untuk melakukan tugas tambahan, memberikan dukungan, atau membela tujuan organisasi, atau terlibat dalam perilaku warga lain jika mereka memiliki tingkat kepuasan yang rendah dengan pekerjaan.

Berdasarkan koefisien bobot factor maka dapat dinyatakan bahwa dalam upaya meningkatkan OCB melalui kepuasan kerja dapat dilakukan dengan cara meningkatkan 
kompetensi supervisor dan memberikan pekerjaan yang menarik karena terbukti kedua indicator ini memiliki bobot factor terendah. Kemudian untuk indikator yang sudah baik yaitu perlakuan adil dan hubungan baik dengan sesama rekan harus terus dipertahankan untuk menjaga komitmen afektif pegawai.

\section{Komitmen afektif berpengaruh terhadap Organizational Citizenship Behavior pegawai Badan Penelitan dan Pengembangan, Pendidikan dan Pelatihan dan Informasi.}

Berdasarkan hasil penelitian berhasil dibuktikan adanya pengaruh positif komitmen afektif terhadap OCB. Pengaruh langsung komtimen afektif terhadap OCB berdasarkan nilai koefisien standard adalah sebesar 0,24 dan t hitung sebesar 2.10, atau naik turunnya OCB mampu dijelaskan oleh POS sebesar $6.25 \%\left(0,25^{2}\right.$ x $\left.100 \%\right)$, sedangkan sisanya $93.75 \%(100 \%-6.25 \%)$ dipengaruh faktor lain. Dapat dinyatakan bahwa semakin tinggi komitmen afektif pegawai di Badan Penelitan dan Pengembangan, Pendidikan dan Pelatihan, dan Informasi akan berimplikasi pada tingginya OCB.

Berdasarkan koefisien bobot faktor diketahui kebanggan pegawai pada organisasi (AFC2), merasa masalah organisasi menjadi masalah diri (AFC3), kedekatan emosi (AFC5) dan merasa organisasi memberikan makna (AFC6) merupakan indikator paling dominan dalam menjelaskan komitmen afektif. Sedangkan indikator terendah adalah merasa menjadi bagian keluarga dari organisasi (AFC4). Dengan demikian, implikasi temuan ini organisasi perlu mempertahankan kebanggaan, kecintaan, kebermaknaan kerja kepada pegawai. Selain itu, perlu memberikan perhatian pada upaya untuk menciptakan suasana kekeluargaan karena teridentifikasi sebagai indikator yang memiliki koefisien bobot faktor terendah.

Pegawai yang mempunyai komitmen merupakan aset penting bagi organisasi. Komitmen pegawai yang tinggi pada organisasi akan memberikan kontribusi positif pada pencapaian tujuan organisasi. Salah satu bentuk dari komitmen pegawai adalah kesediaan mereka untuk berperilaku ekstra peran atau sering disebut dengan istilah Organizational Citizenship Behaviour. Kesediaan pegawai untuk secara sukarela mengerjakan tugas atau pekerjaan yang bukan merupakan bagian tugasnya merupakan perilaku positif yang harus ditingkatkan. Berdasarkan hal tersebut maka penting bagi pimpinan Badan Penelitan dan Pengembangan, Pendidikan dan Pelatihan, dan Informasi untuk mengembangkan komitmen pegawai dan memperhatikan kebutuhan pegawai dengan memberikan kepuasan dalam bekerja. Pihak pimpinan perlu meningkatkan komitmen pegawai pada organisasi dan meningkatkan kepuasan pegawai dalam bekerja dengan mengimplementasikan beberapa strategi sumber daya manusia yang relevan dan sekiranya mampu meningkatkan perilaku ekstra peran dari pegawai.

Tabel 4. Model Struktural

\begin{tabular}{|l|l|l|}
\hline No & Model & Model Struktural \\
\hline 1 & SAT & SAT $=0.589 * \mathrm{POS}+0.653$ \\
\hline 2 & AFC & AFC $=0.448 * \mathrm{SAT}+0.379 * \mathrm{POS}+0.455$ \\
\hline 3 & OCB & OCB $=0.308 * \mathrm{SAT}+0,250 * \mathrm{AFC}+0,239 * \mathrm{POS}+0.518$ \\
\hline
\end{tabular}

Sumber : Hasil pengolahan data

Keterangan : 


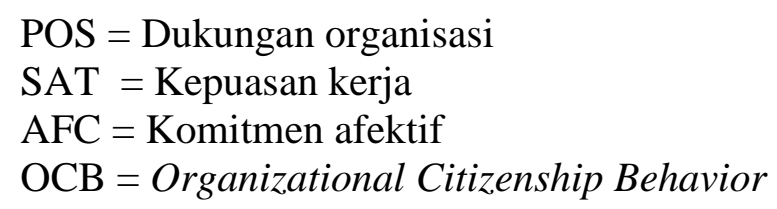

\section{KESIMPULAN DAN SARAN Kesimpulan}

Berdasarkan hasil analisis yang sudah dijelaskan pada Bab IV, maka kesimpulan yang berhasil diperoleh antara lain : Persepsi dukungan organisasi berpengaruh positif dan signifikan terhadap kepuasan kerja. Dengan demikian hipotesis 1 terbukti bahwa semakin tinggi persepsi dukungan organisasi yang dirasakan oleh pegawai akan berimplikasi pada tingginya kepuasan kerja pegawai. Persepsi dukungan organisasi berpengaruh positif terhadap komitmen afektif. Dengan demikian hipotesis 2 terbukti bahwa bahwa semakin tinggi persepsi dukungan organisasi yang dirasakan oleh pegawai akan berimplikasi pada tingginya komitmen afektif pegawai. Kepuasan kerja berpengaruh positif terhadap komitmen afektif. Dengan demikian hipotesis 3 terbukti bahwa semakin tinggi kepuasan kerja yang dirasakan oleh pegawai akan berimplikasi pada tingginya komitmen afektif. Persepsi dukungan organisasi berpengaruh positif terhadap organizational citizenship behavior. Dengan demikian hipotesis 4 terbukti bahwa semakin tinggi persepsi dukungan organisasi yang dirasakan oleh pegawai akan berimplikasi pada tingginya organizational citizenship behavior. Kepuasan kerja berpengaruh positif terhadap organizational citizenship behavior. Dengan demikian hipotesis 5 terbukti bahwa semakin tinggi kepuasan kerja yang dirasakan oleh pegawai akan berimplikasi pada tingginya organizational citizenship behavior. Komitmen afektif berpengaruh positif terhadap organizational citizenship behavior. Dengan demikian hipotesis 6 terbukti bahwa semakin tinggi komitmen afektif pegawai akan berimplikasi pada tingginya organizational citizenship behavior.

\section{Saran}

Beberapa saran terkait dengan keterbatasan dan implikasi yang sudah dijelaskan pada bagian terdahulu antara lain :

a. Kepada Pimpinan Badan Penelitian Pengembangan dan Informasi (Balifo) Kementerian Tenaga Kerja dan Transmigrasi perlu memberikan dukungan terhadap pegawainya, meningkatkan komitmen pegawai dan memperhatikan kebutuhan pegawai dengan memberikan kepuasan dalam bekerja dengan mengimplementasikan beberapa strategi sumber daya manusia yang relevan dan sekiranya mampu meningkatkan perilaku ekstra peran dari pegawai.

b. Kepada para peneliti :

1. Penelitian ini menggunakan design cross-sectional sehingga memiliki kelemahan dalam memberikan penjelasan kausalitas hubungan antar variabel. Disarankan untuk penelitian mendatang menggunakan design longitudinal untuk memperkuat pembuktian empiris pada hubungan kausal antar variabel.

2. Penelitian ini dilakukan hanya pada Badan Penelitian Pengembangan dan Informasi (Balifo) Kementerian Tenaga Kerja dan Transmigrasi sehingga tidak bisa digeneralisasi secara umum untuk seluruh Pegawai Negeri Sipil (PNS). 
Riset lanjutan disarankan untuk melakukan penelitian lintas kementerian untuk memperkuat generalisasi hasil.

3. Kepada para pembaca yang melihat masih banyaknya kelemahan-kelemahan dalam penelitian ini untuk memberikan kritik, sumbang saran yang dapat dijadikan masukan dalam penyempurnaan penulisan ini.

\section{DAFTAR PUSTAKA}

Alizadeh, M. 2010. Explain The Role Of Organizational Culture On Organizational Citizenship Behavior, Organizational, Conference of Management of Organizational Citizenship Behavior, Tehran University, School of Management.

Azizollah, Arbabisarjou; Hajipour, Reza; Mahdi, Sadeghian Sourki. ,2014, The Correlation Between Justice and Organizational Citizenship Behavior and Organizational Identity Among Nurses, Global Journal of Health Science Vol. $6.6,2014$, pp. 252-260.

Budiharjo, Andreas. 2011, Organisasi : Menuju Pencapaian Kinerja Optimum, Prasetya Mulya Publishing, Jakarta.

Chahal, Hardeep; Mehta, Shivani. 2011, Antecedents And Consequences Of Organisational Citizenship Behaviour (OCB): A Conceptual Framework In Reference To Health Care Sector, Journal of Services Research Vol. 10.2 ,Oct 2010-Mar 2011, pp. 25-44.

Chen, Chien-Cheng; Chiu, Su-Fen. 2009, The Mediating Role of Job Involvement in the Relationship Between Job Characteristics and Organizational Citizenship Behavior, The Journal of Social Psychology Vol. 49.4 ,Aug 2009, pp. 474-94.

Duffy, Jo Ann; Lilly, Juliana. 2013, Do Individual Needs Moderate the Relationships between Organizational Citizenship Behavior, Organizational Trust and Perceived Organizational Support?. Journal of Behavioral and Applied Management Vol. 14.3, May 2013, pp. 185-197.

Farhan Mehboob, Niaz A Bhutto. 2012, Job Satisfaction as a Predictor of Organizational Citizenship Behavior. International Confrence on Business, Economics, Management and Behavioral Science (ICBEMBS 2012). Jan 7 - 8, 2012, Dubai

Hair, J.F., et al. ,2014, Multivariate Data Analysis (7th edition), Pearson Education Inc. New Jersey.

Jain, Ajay K; Giga, Sabir I; Cooper, Cary L. ,2013, Perceived Organizational Support As A Moderator In The Relationship Between Organisational Stressors And Organizational Citizenship Behaviors, International Journal of Organizational Analysis Vol. 21.3, 2013, pp. 313-334.

Lee, Ung Hee; Kim, Hye Kyoung; Kim, Young Hyung, 2013, Determinants of Organizational Citizenship Behavior and Its Outcomes. Global Business and Management Research V. 5.1 (2013), pp. 54-65.

Meyer, J. P., Stanley, D. J., Herscovitch. L., \& Topolnytsky, L. ,2012, Affective, Continuance, And Normative Commitment To The Organization: A MetaAnalysis Of Antecedents, Correlates, And Consequences, Journal of Vocational Behavior. 6/(1), 2D-52. 
Miao, Ren-Tao., 2011, Perceived Organizational Support, Job Satisfaction, Task Performance and Organizational Citizenship Behavior in China, Journal of Behavioral and Applied Management 12.2 ,Jan 2011, pp. 105-127.

Peelle, Henry E, III, DM. 2007. Reciprocating Perceived Organizational Support through Citizenship Behaviors. Journal of Managerial Issues V.19.4., Winter 2007, pp. 554-575,459-460.

Piercy, Nigel F; Cravens, David W; Lane, Nikala; Vorhies, Douglas W. 2006. Driving Organizational Citizenship Behaviors and Salesperson In-Role Behavior Performance: The Role of Management Control and Perceived Organizational Support, Academy of Marketing Science. Journal V. 34.2 (Spring 2006): pp. 244262.

Podsakoff, P.M., MacKenzie, S.B., Paine, J.B. and Bachrach, D.G. 2009, "Organizational Citizenship Behaviors: A Critical Review Of The Theoretical And Empirical Literature And Suggestions For Future Research", Journal of Management, Vol. 26 No. 3, pp. 513-63.

Qamar, Nida., 2012,. Job Satisfaction And Organizational Commitment As Antecedents Of Organizational Citizenship Behavior (OCB). Interdisciplinary Journal of Contemporary Research In Business V. 4.7 (Nov 2012): pp. 103-122.

Rahmi, B.M. 2013, Pengaruh Kepemimpinan Transformasional Terhadap Organizational Citizenship Behavior Dan Komitmen Organisasional Dengan Mediasi Kepuasan Kerja. Tesis Magister Manajemen, Program Pascasarjana Universitas Udayana tahun 2013. Tersedia di www.pps.unud.ac.id/thesis/

Robbins, Stephen P.;Coulter, Mary. 2010,. Management. (11 ed). Pearson Education, Inc

Setyawan, H. ,2009,. Pengaruh Komitmen Organisasional Terhadap Kepuasan Kerja Dengan Organizational Citizenship Behavior (OCB) Sebagai Variabel Intervening. (Studi pada Inspektorat Kabupaten Temanggung). Tesis Magister Akuntansi, Universitas Diponegoro tahun 2009. Tersedia di eprints.undip.ac.id/

Sharma, Jai Prakash; Bajpai, Naval; Holani, Umesh. 2011, Organizational Citizenship Behavior in Public and Private Sector and Its Impact on Job Satisfaction: A Comparative Study in Indian Perspective. International Journal of Business and Management V. 6.1 (Jan 2011): 67-75.

Titisari, Purnamie. 2014. Peranan Organizational Citizenship Behavior (OCB) Dalam Meningkatkan Kinerja Karyawan. Jakarta: Mitra Wacana Media.

Wang, Zhongmin, 2014, Perceived Supervisor Support and Organizational Citizenship Behavior: The Role of Organizational Commitment. International, Journal of Business and Social Science Vol. 5. Jan 2014, pp. 215-285.

Wei Zheng, Mian Zhang, Hai Li, 2012, "Performance Appraisal Process And Organizational Citizenship Behavior", Journal of Managerial Psychology, Vol. 27 Iss: 7, pp.732 - 752

Williams, Steve; Pitre, Richard; Zainuba, Mohamed., 2002, Justice And Organizational Citizenship Behavior Intentions: Fair Rewards Versus Fair Treatment, The Journal of Social Psychology 142.1, Feb 2002, pp. 33-44. 